\title{
A second, cryptic species of the soft coral genus Incrustatus (Anthozoa: Octocorallia: Clavulariidae) from Tierra del Fuego, Argentina, revealed by DNA barcoding
}

\author{
Catherine S. McFadden • Leen P. van Ofwegen
}

Received: 17 January 2012/Revised: 10 April 2012/Accepted: 20 April 2012/Published online: 6 May 2012

(C) Springer-Verlag and AWI 2012

\begin{abstract}
The encrusting soft coral Incrustatus comauensis is a common denizen of hard substrates in the shallow sub-tidal zone from the central Chilean fjords to the Cape Horn region of southern South America. DNA barcoding of specimens collected from the Beagle Channel, Tierra del Fuego, Argentina, revealed the presence of a second, cryptic species of Incrustatus that is syntopic with I. comauensis. We describe Incrustatus niarchosi, a new species that can be distinguished morphologically from I. comauensis by differences in the microscopic ornamentation of the coenenchymal sclerites. To date, I. niarchosi n. sp. is known only from the Beagle Channel. A population of I. comauensis discovered in the intertidal zone in eastern Tierra del Fuego represents a new record of the species for that habitat and geographic region. Although the intertidal population is also distinct genetically, it is morphologically indistinguishable from sub-tidal Chilean populations of I. comauensis, and at present, there is insufficient evidence to support its status as a separate species.
\end{abstract}

Keywords Alcyonacea $\cdot$ Cnidaria $\cdot \mathrm{COI} \cdot \mathrm{mtMutS}$. $28 \mathrm{~S}$ rDNA $\cdot$ New species $\cdot$ Intertidal

Communicated by Heinz-Dieter Franke.

C. S. McFadden $(\bowtie)$

Department of Biology, Harvey Mudd College,

Claremont, CA 91711, USA

e-mail: mcfadden@hmc.edu

L. P. van Ofwegen

Netherlands Centre for Biodiversity Naturalis, P.O. Box 9517, 2300 RA Leiden, The Netherlands

e-mail: leen.vanofwegen@ncbnaturalis.nl; ofwegen@yahoo.com

\section{Introduction}

van Ofwegen et al. (2006) recently described Incrustatus comauensis, a new genus and species of soft coral from the southern Chilean fjord region. The species has a stoloniferous to membranous growth form and is typically found growing as a thin crust on hard surfaces, including biogenic substrates such as mollusk shells, polychaete tubes, and the axes of gorgonians. To date, I. comauensis is known to occur in the shallow sub-tidal to a depth of $30 \mathrm{~m}$ along the Chilean coast and fjord region from Dichato $\left(36^{\circ} \mathrm{S}\right)$ to the Bernardo fjord $\left(48^{\circ} \mathrm{S}\right)$ (van Ofwegen et al. 2006, 2009). It has also been reported from several sites in the Magellan region of Chile including the Straits of Magellan $\left(53^{\circ} \mathrm{S}\right)$ and the Murray Channel $\left(55^{\circ} \mathrm{S}\right)$ (Cárdenas et al. 2008) (Fig. 1). Although the southernmost Chilean coastal regions remain poorly known, this species would appear to be a common member of shallow sub-tidal rocky communities throughout this broad geographic range; it is absent only from areas of high glacial sedimentation (van Ofwegen et al. 2006). Here, we document the occurrence of I. comauensis in the shallow sub-tidal of the Beagle Channel, Tierra del Fuego, Argentina $\left(54.5^{\circ} \mathrm{S}\right)$. In addition, we note the first record of a population of I. comauensis in an intertidal habitat, a genetically distinct population from the Atlantic Coast of Tierra del Fuego (53.3ㅇ).

The application of DNA barcoding to octocorals has been problematic because of the low rates of mitochondrial gene evolution in anthozoan cnidarians relative to other animal taxa (Shearer et al. 2002; Hellberg 2006). Although other mitochondrial gene regions, most notably the octocoral-specific mitochondrial mutS homolog ( $m t M u t S$, previously known as $m s h 1$ ), appear to be somewhat better barcodes for octocorals than the widely used cytochrome oxidase I $(C O I)$, both mitochondrial markers still only 


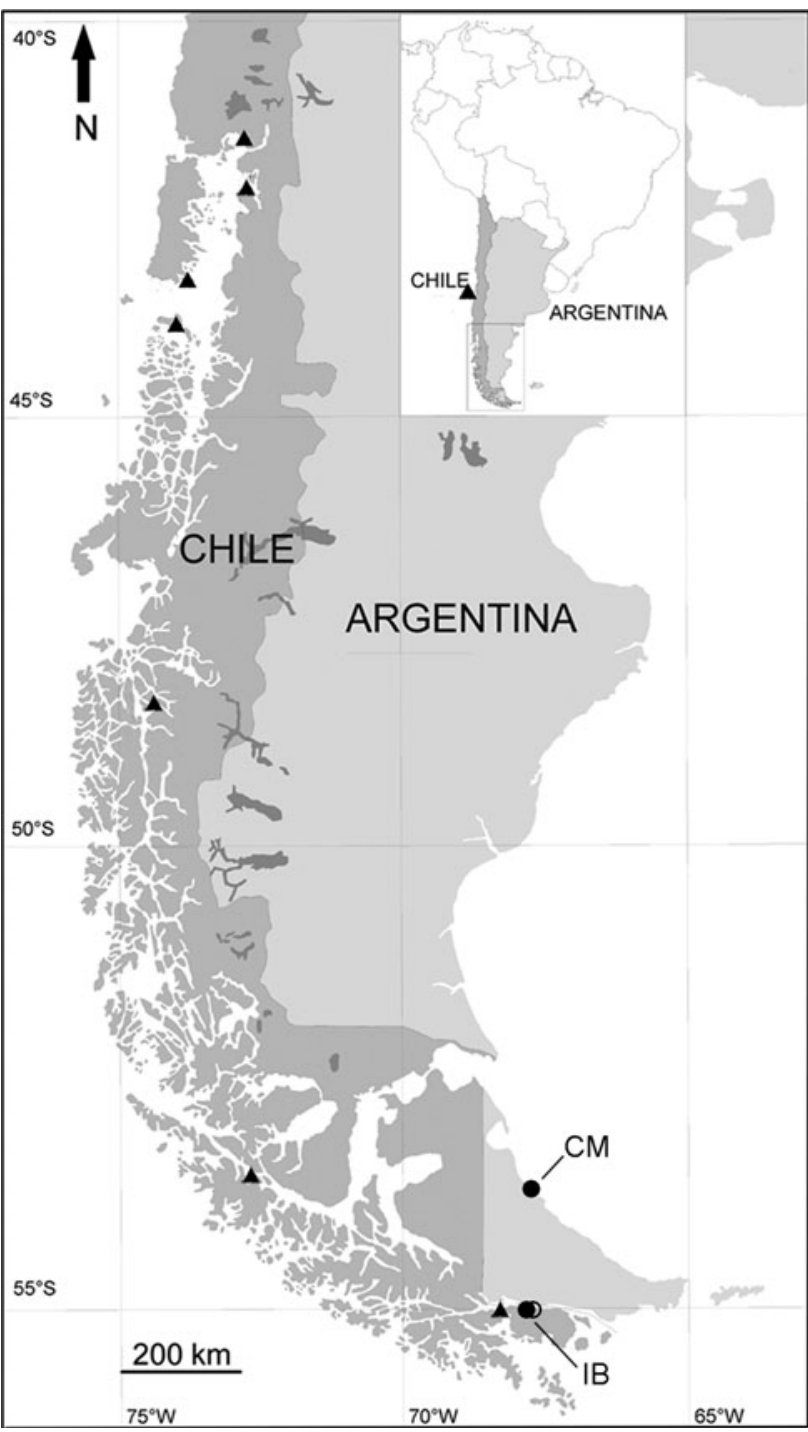

Fig. 1 Map of southern South America showing locations where Incrustatus has been documented to occur. Filled triangle locations at which I. comauensis has been collected in previous studies (van Ofwegen et al. 2006; Cárdenas et al. 2008); filled circle new collections of $I$. comauensis reported in this study; open circle location of $I$. niarchosi n. sp.; $I B$ Isla Bridges, $C M$ Caleta la Mission. Inset shows area of map and one additional location. Map modified from van Ofwegen et al. (2006)

discriminate about $70-80 \%$ of congeneric species (McFadden et al. 2011). Despite their inability to separate some closely related species, however, the use of DNA barcodes in biodiversity surveys has already proven useful for detecting cryptic species in octocorals, taxa for which there is often a paucity of morphological characters available for taxonomy (McFadden et al. 2006, 2011).

As part of our ongoing efforts to develop more effective barcode markers for octocorals, material collected from Tierra del Fuego was sequenced for COI, mtMutS, and a nuclear gene region (28S rDNA). The sequences obtained from all three genes unexpectedly revealed the presence of a second, morphologically cryptic species of Incrustatus in the Beagle Channel, and flagged the intertidal population from eastern Tierra del Fuego as a genetically distinct entity whose species status warrants further investigation.

\section{Materials and methods}

\section{Collection}

Soft corals were collected from 28 to 31 December 2010 using SCUBA. Eight dives at depths from 4 to $21 \mathrm{~m}$ were made in the Beagle Channel in the vicinity of Ushuaia, Tierra del Fuego, Argentina $\left(54.5^{\circ} \mathrm{S}, 68.1^{\circ} \mathrm{W}\right)$ (Fig. 1). In addition, material was collected intertidally at Caleta la Mission, $20 \mathrm{~km}$ northwest of Rio Grande, Tierra del Fuego, Argentina $\left(53^{\circ} 36.125^{\prime} \mathrm{S}, 67^{\circ} 57.928^{\prime} \mathrm{W}\right)$. Vouchers were preserved in $70 \% \mathrm{EtOH}$ with small pieces of tissue stored separately in $95 \%$ EtOH for DNA. Vouchers and type material have been deposited at Museo Argentino de Ciencias Naturales Bernardino Rivadavia, Buenos Aires (MACN) and at the American Museum of Natural History, New York (AMNH). Newly collected material was compared to type material for I. comauensis held at the Netherlands Centre for Biodiversity Naturalis (formerly Rijksmuseum van Natuurlijke Historie, Leiden) (RMNH).

\section{Morphological analysis}

Sclerites were obtained by dissolving tissues from a colony in $10 \%$ sodium hypochlorite (household bleach). Sclerites were rinsed well with deionized water, dried, and mounted on stubs for SEM. They were imaged using a JSM-6480LV scanning electron microscope operated at $10 \mathrm{kV}$.

\section{Molecular analysis}

Extraction of DNA from ethanol-preserved tissue samples, PCR amplification, and sequencing of the mtMutS (mshl) and COI genes followed the protocols published in McFadden et al. (2011). In addition, we sequenced an approximately $810 \mathrm{nt}$ fragment of the $28 S$ nuclear ribosomal gene using primers 28S-Far (5'-CACGAGACCGATAGCGAA CAAGTA- $\left.3^{\prime}\right)$ and either 28S-Rar (5'-TCATTTCGACCC TAAGACCTC- $\left.3^{\prime}\right)$ or 28S-Rab (5'-TCGCTACGAGCTT CCACCAGTGTTT- $3^{\prime}$ ), and the same PCR protocol used for COI. Sequence data were proofread using LaserGene software and aligned using MUSCLE v. 3.6 (Edgar 2004). MEGA v. 5 (Tamura et al. 2011) was used to calculate pairwise genetic distances (uncorrected $\mathrm{p}$ ) among specimens. Sequences were deposited in GenBank (accession numbers JQ904901-JQ904910) and compared to reference 
sequences from I. comauensis paratype RMNH Coel. 33872 (GenBank nos. GQ342391, GQ342475).

\section{Results}

Colonies of I. comauensis were collected sub-tidally at five of eight dive sites in the Beagle Channel, including four shallow, rocky areas (4-8 m depth) within the Islas Bridges Archipelago and a deeper rock reef (18-21 m depth) in the center of the channel. All specimens were very similar both morphologically and genetically to those from the type locality in Comau fjord, Chile, a site $>1,500 \mathrm{~km}$ distant. No differences were observed in the form of the coenenchymal sclerites in specimens from the two different locations (Figs. 2, 3), and all of the specimens of I. comauensis from the Beagle Channel that we sequenced $(n=8)$ were genetically identical to paratype RMNH Coel. 33872 from Comau fjord at all three loci (mtMutS, COI and $28 S$ rDNA). Most of the colonies we found in the Beagle Channel were, however, quite small and growing attached to rock surfaces (Fig. 4c) rather than on other organisms as has been reported in other parts of their geographic range (van Ofwegen et al. 2006; Cárdenas et al. 2008).

At Caleta la Mission, an area of rocky shore $20 \mathrm{~km}$ northwest of Rio Grande on the Atlantic coast of Tierra del Fuego, we found an extensive population of I. comauensis growing on mussels and rock surfaces under overhangs in the intertidal. Areas up to $1 \mathrm{~m}^{2}$ were covered with dense aggregations of colonies that were larger and somewhat thicker than those we encountered sub-tidally (Fig. $4 d-$ f). DNA barcoding of specimens from this population $(n=4)$ revealed them to be genetically distinct at two of the three loci analyzed, differing from I. comauensis RMNH Coel. 33872 by $0.7 \%$ at $\mathrm{COI}$ and $0.8 \%$ at $28 \mathrm{~S}$ rDNA, but sharing the same $m t M u t S$ haplotype. There are no apparent differences in the sclerites of this population (Fig. 5), however, which appear identical to those of I. comauensis from Comau fjord (Fig. 2) and the Beagle Channel (Fig. 3). The only morphological difference we have been able to detect is a complete absence of sclerites in the polyps of the intertidal population whereas the sub-tidal populations of I. comauensis have sparse rods in the polyps (Figs. 2, 3). Lacking evidence of any further differences between them, we conclude that this intertidal population is merely a genetically and ecologically distinct population of I. comauensis. Voucher specimens of this distinct genotype have been deposited at MACN and AMNH.

At two shallow sub-tidal sites within the Isla Bridges Archipelago, Beagle Channel, we collected two individuals of Incrustatus that differed from I. comauensis by genetic distances (uncorrected p) of $1.0 \%$ at $m t M u t S, 1.0 \%$ at
$\mathrm{COI}$, and $3.6 \%$ at $28 \mathrm{~S}$ rDNA. These distances are greater than those found among individuals of the same species in any genus of octocorals examined to date (McFadden et al. 2011) and suggest that these colonies belong to a new, cryptic species of Incrustatus. Although this new species appears to be indistinguishable from I. comauensis in the field, differences in the microscopic ornamentation of the coenenchymal sclerites support its status as a distinct species.

Taxonomic Account

Order Alcyonacea Lamouroux, 1816

Family Clavulariidae Hickson, 1894

Genus Incrustatus Ofwegen, Häusserman \& Försterra, 2006

Incrustatus niarchosi, new species. Figures 4a-b, 6, 7.

Material examined

Holotype: MACN-IN 39266, Argentina, Tierra del Fuego, Beagle Channel, Islas Bridges, $54^{\circ} 51.886^{\prime} \mathrm{S}, 68^{\circ} 14.933^{\prime} \mathrm{W}$, depth 6 m, coll. C. S. McFadden, December 30, 2010. Paratype: AMNH Acc. 65678, Cnidaria coll. 6040, Argentina, Tierra del Fuego, Beagle Channel, Islas Bridges, Isla H, depth 5-6 m, coll. D. Lauretta, December 31, 2010. Other material: RMNH Coel. 33872, I. comauensis, paratype, Chile, Comau, wall north of Punta Llonco, $42^{\circ} 19.894^{\prime} \mathrm{S}$, $72^{\circ} 27.661^{\prime} \mathrm{W}$, depth $14.5 \mathrm{~m}$, coll. V. Häussermann and G. Försterra, December 25, 2004. MACN-IN 39267, I. comauensis, Argentina, Tierra del Fuego, Beagle Channel, Islas Bridges, $54^{\circ} 51.886^{\prime} \mathrm{S}, 68^{\circ} 14.933^{\prime} \mathrm{W}$, depth $6 \mathrm{~m}$, coll. C. S. McFadden, December 30, 2010. MACN-IN 39268, I. comauensis, Argentina, Tierra del Fuego, $20 \mathrm{~km} \mathrm{NW}$ of Rio Grande, Caleta la Mission, $53^{\circ} 36.125^{\prime} \mathrm{S}, 67^{\circ} 57.928^{\prime} \mathrm{W}$, intertidal, coll. C. S. McFadden, January 03, 2011.

\section{Description}

The holotype is a thinly encrusting colony that was removed from rock substrate at the time of collection (Fig. 4a, b). This fragment measures $1.4 \mathrm{~cm}$ by $1.0 \mathrm{~cm}$ and has about 45 polyps embedded within a surrounding membrane that is $1.5 \mathrm{~mm}$ thick. Most of the polyps are completely retracted within the membrane and are visible only as slight coenenchymal mounds with a central pore (Fig. 4b).

The sclerites of the coenenchyme are 8-radiates, blunt spindles, and ovals with a distinct median waist, ranging from 0.05 to $0.12 \mathrm{~mm}$ in length (Fig. 6b). All but the smallest radiates have large, complex tubercles with dense ornamentation. Some sclerites have much of the tubercular sculpture rounded and smoother on one side (Fig. 6c). The 


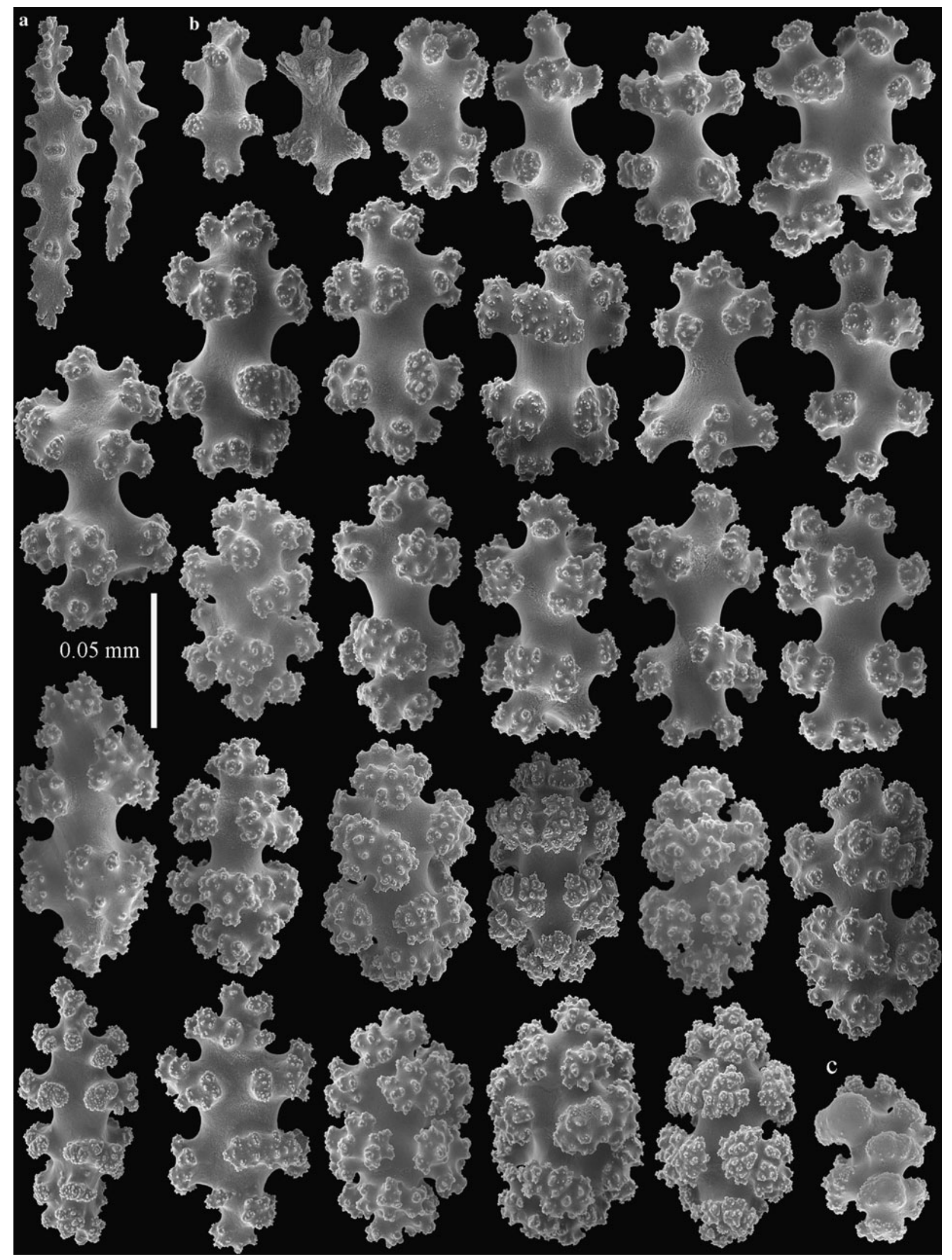

Fig. 2 Incrustatus comauensis, paratype RMNH Coel. 33872. a polyp sclerites, $b$ sclerites of coenenchyme, $c$ coenenchymal sclerite with smooth-surfaced tubercles arranged unilaterally 


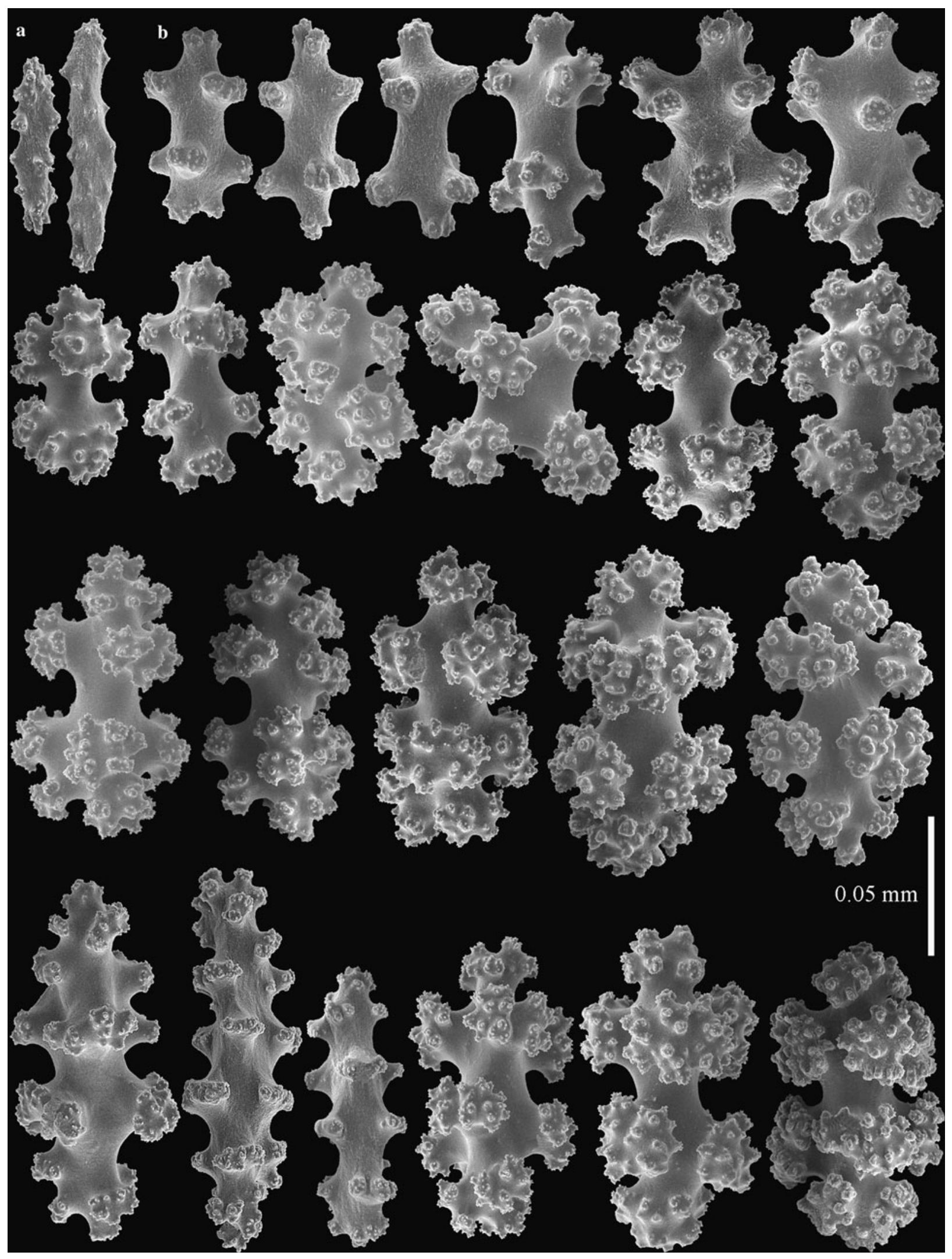

Fig. 3 Incrustatus comauensis, MACN-IN 39267. a polyp sclerites, $b$ sclerites of coenenchyme 

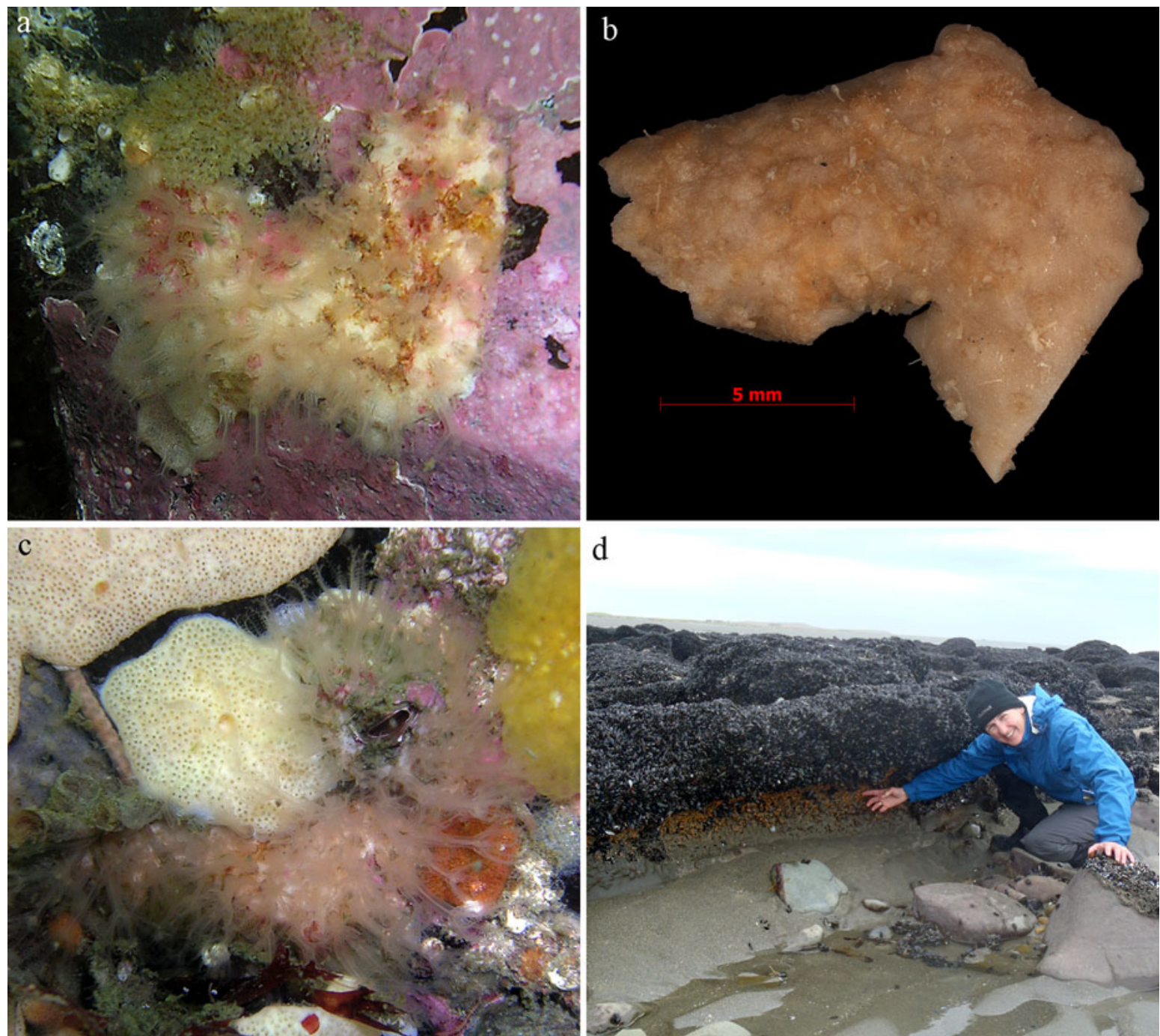

d
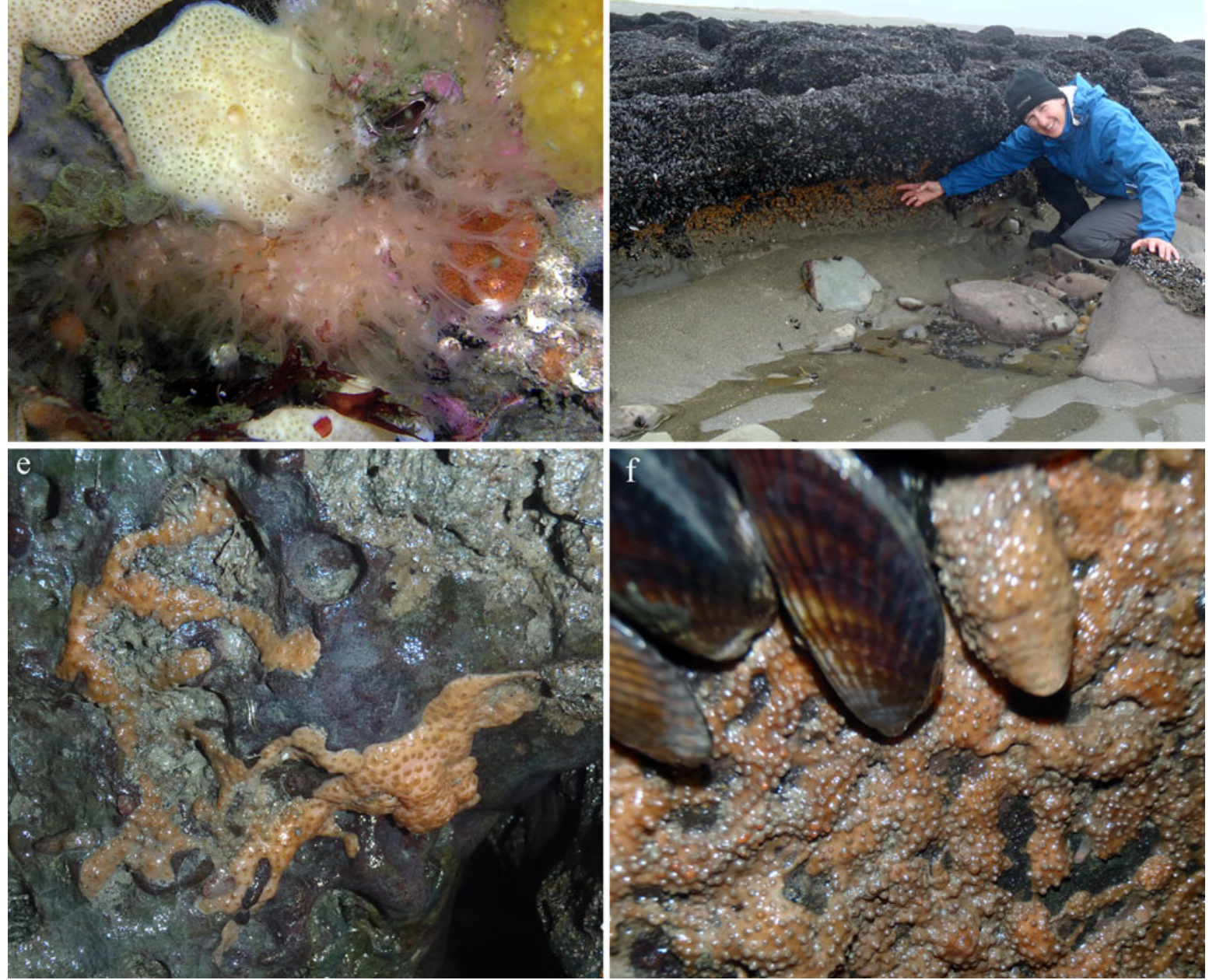

Fig. 4 a Incrustatus niarchosi n. sp. holotype, MACN-IN 39266, photographed in situ; b Incrustatus niarchosi n. sp. holotype, MACNIN 39266; c I. comauensis, photographed at same location as (a); d I. comauensis, intertidal population at Caleta la Mission, Tierra

del Fuego, Argentina; e, f, colonies of I. comauensis growing under rock overhangs in the intertidal, Caleta la Mission, Tierra del Fuego, Argentina 


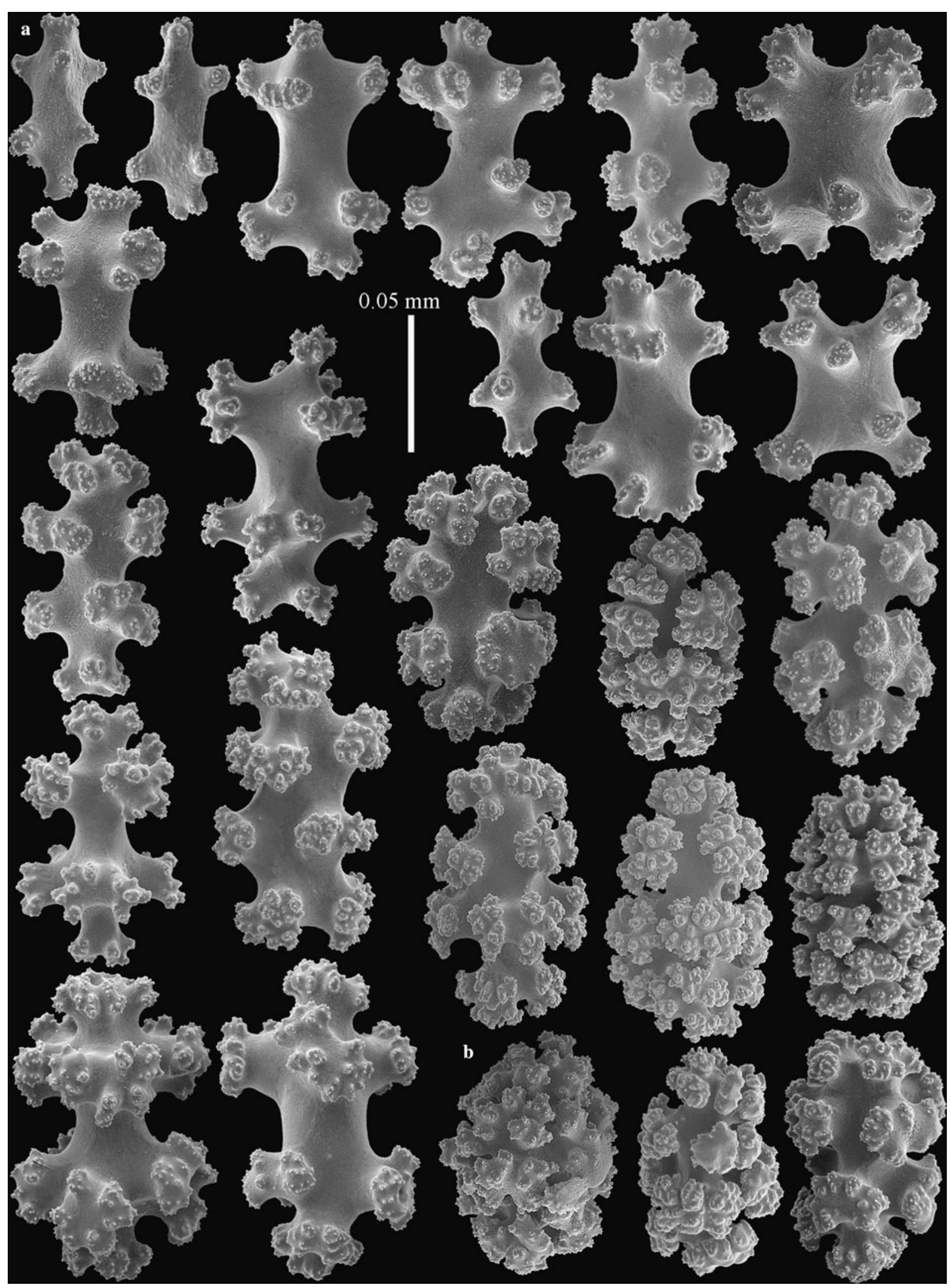

Fig. 5 Incrustatus comauensis, MACN-IN 39268. $a$ sclerites of coenenchyme, $b$ coenenchymal sclerites with smooth-surfaced tubercles arranged unilaterally 


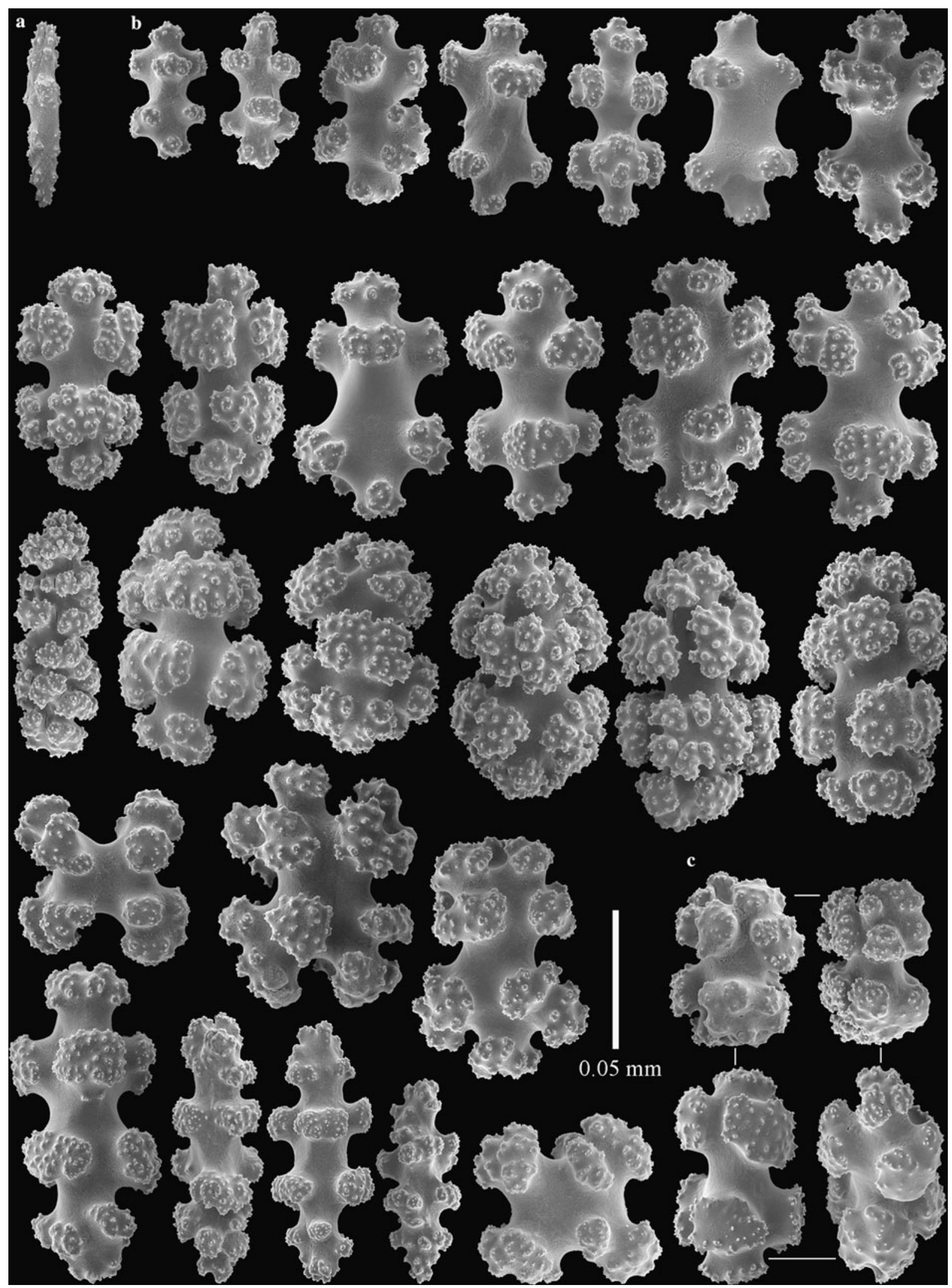

Fig. 6 Incrustatus niarchosi $\mathrm{n}$. sp. holotype, MACN-IN 39266. $a$ polyp sclerite, $b$ sclerites of coenenchyme, $c$ coenenchymal sclerites with smooth-surfaced tubercles arranged unilaterally 
polyps have only a few rods, $0.07 \mathrm{~mm}$ long, with simple tubercles (Fig. 6a).

The paratype is a similar fragment removed from rock substrate, smaller than the holotype, and with all polyps retracted. The sclerites are very similar to those of the holotype, except that no polyp sclerites were found (Fig. 7). This does not necessarily indicate that the specimen lacks polyp sclerites, merely that they are rare relative to the numbers of coenenchymal sclerites.

Color in life, cream with transparent polyps (Fig. 4a). Light brown in EtOH.

\section{Etymology}

Named in honor of the Niarchos Family Foundation, whose Constantine S. Niarchos Expeditions Award to E. Rodriguez funded the expedition to Tierra del Fuego.

\section{Remarks}

Morphologically, I. niarchosi $\mathrm{n}$. sp. is very similar to $I$. comauensis, differing only in the tubercular sculpture of the radiates and oval sclerites found in the coenenchyme. In I. niarchosi $\mathrm{n}$. sp. the tubercular sculpture is finer and denser compared to the coarser tubercular sculpture on sclerites of I. comauensis. This difference can be seen readily by comparing Figs. 6 and 7 with images of the sclerites of I. comauensis (Figs. 2, 3, 5). Although the two species of Incrustatus can be distinguished by these differences in microscopic sclerite ornamentation, we were unable to distinguish them morphologically in the field (Fig. 4a, c). The DNA sequence differences at all three loci support their distinction as separate but sympatric species.

\section{Discussion}

The uses and usefulness of DNA barcoding for species discovery have been widely discussed and hotly debated from both philosophical and practical perspectives (e.g. Smith 2005; Hickerson et al. 2006; DeSalle 2006; Rubinoff 2006; Wiens 2007). This study, however, is one of a growing number (Bucklin et al. 2011) that highlight the benefits of using DNA barcodes to flag new, morphologically cryptic species that would have gone unrecognized otherwise. Routine DNA barcoding of the Incrustatus specimens we collected in the Beagle Channel first revealed the existence of genetically distinct individuals, after which their status as a previously unrecognized species was corroborated by the examination of microscopic morphological characters. The combined evidence of relatively large genetic differences at both mitochondrial and nuclear loci linked to diagnostic morphological traits is strong evidence that these two species, which co-occur in close proximity within the same habitat, are reproductively isolated.

The sympatric occurrence of two such similar yet apparently reproductively isolated congeners raises questions of their origin and co-existence in the Beagle Channel. Both species were collected at the same sites, where there appeared to be a single, homogeneous population of Incrustatus colonies growing on vertical and horizontal rock surfaces in the shallow sub-tidal. Although further ecological work might reveal microhabitat differences we did not detect, our preliminary collections do not suggest any differences in depth or habitat use among these cryptic congeners. I. comauensis is known to have a wide geographic range, occurring along a $2000 \mathrm{~km}$ stretch of the Chilean coast from Dichato $\left(36^{\circ} \mathrm{S}\right)$ to Tierra del Fuego $\left(55^{\circ} \mathrm{S}\right)$ (van Ofwegen et al. 2006; Cárdenas et al. 2008). To date, I. niarchosi $\mathrm{n}$. sp. is known only from the Beagle Channel. Without further information about the geographic range of this species, it is difficult to speculate about the mechanisms that might have led to the co-occurrence of two such similar congeners in the Beagle Channel. One possibility is that $I$. niarchosi $\mathrm{n}$. sp. occupies a more southern range than I. comauensis, and that one or both species has recently expanded its range into the Beagle Channel. Another possibility is that one species has been introduced from elsewhere. Ushuaia is a major port for ship traffic around Cape Horn and from Antarctica (Frenot et al. 2005), and the possibility therefore exists for species to have been introduced to the Beagle Channel from other geographic regions. Sites where I. comauensis is known to occur should be checked carefully for the presence of I. niarchosi $\mathrm{n}$. sp. to determine whether that species' presence has been overlooked in past studies.

Although DNA barcoding also revealed genetic differences between typical sub-tidal populations of I. comauensis and a newly discovered intertidal population, integrated taxonomic approaches do not yet support their status as separate species. Although a genetic difference of $0.7 \%$ at $\mathrm{COI}$ is at the upper end of the range of values normally observed among conspecific individuals in octocorals (McFadden et al. 2011), the morphological differences that distinguish these two ecotypes are very slight (no vs. very few polyp sclerites). The two ecotypes also share identical DNA sequences at $m t M u t S$, a locus that is typically more variable than $\mathrm{COI}$ in octocorals (McFadden et al. 2011). Further study of ecological, reproductive, and biogeographical differences among the sub-tidal and intertidal forms of I. comauensis, might, however, support their status as separate species, as would evidence of genetic differentiation in sympatry.

The genetic differentiation we observed between the intertidal population of I. comauensis at Caleta la Mission 


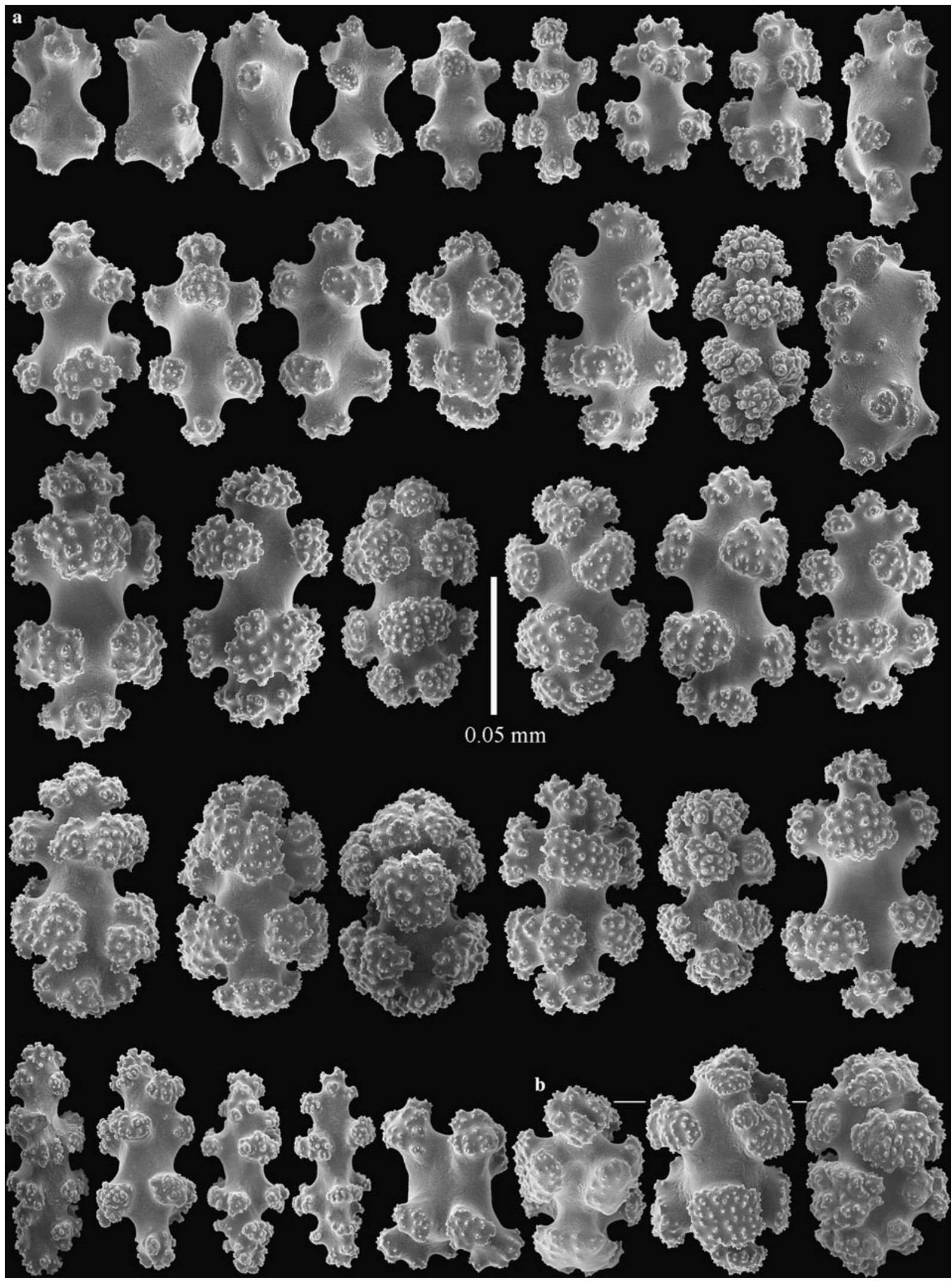

Fig. 7 Incrustatus niarchosi $\mathrm{n}$. sp. paratype, AMNH Acc. 65678, Cnidaria coll. 6040. $a$ sclerites of coenenchyme, $b$ coenenchymal sclerites with smooth-surfaced tubercles arranged unilaterally 
and sub-tidal populations in the Beagle Channel and Chilean fjords can potentially be explained by restricted gene flow among geographically isolated populations. Caleta la Mission is one of only a few isolated areas of rocky shore along the otherwise sandy eastern coast of Tierra del Fuego, and it may be that the population of $I$. comauensis that occurs there is effectively genetically isolated from other populations. We did not find I. comauensis at Cabo Auricosta, another isolated rocky intertidal site $60 \mathrm{~km}$ south. Areas of rocky shore further north along the Argentine coast should be surveyed for the presence of this species and to determine whether the intertidal population at Caleta la Mission is unique both ecologically and genetically or if other similar populations occur.

Acknowledgments We thank E. Rodriguez, D. Lauretta, P. Moell, C. Giuggia and $\mathrm{H}$. Monsalve for assistance with trip logistics, diving and collecting in Argentina; the Subsecretaría de Ciencia y Technología, Ministerio de Economía, Provincia de Tierra del Fuego, Antártida e Islas del Atlántico Sur for issuing collecting permits; A. Lee for DNA sequencing; and B. Reijnen for assistance with photomicroscopy. This work was supported by a Constantine S. Niarchos Expeditions Award to E. Rodriquez from the Niarchos Family Foundation, the Assembling the Cnidarian Tree of Life project (U.S. National Science Foundation grants EF-0531570 to C. S. McFadden and EF-0531779 to P. Cartwright), and a Temminck Fellowship to C. S. McFadden from the Netherlands Centre for Biodiversity Naturalis.

\section{References}

Bucklin A, Steinke D, Blanco-Bercial L (2011) DNA barcoding of marine metazoa. Annu Rev Mar Sci 3:471-508

Cárdenas C, van Ofwegen L, Montiel A, Schories D (2008) First records of Octocorallia (Cnidaria: Anthozoa) to the Cape Horn biosphere reserve, Magellan Region, Chile. Anales Inst Patagonia (Chile) 36:45-52
DeSalle R (2006) Species discovery versus species identification in DNA barcoding efforts: response to Rubinoff. Conserv Biol 20:1545-1547

Edgar RC (2004) MUSCLE: multiple sequence alignment with high accuracy and high throughput. Nucl Acids Res 32:1792-1797

Frenot Y, Chown SL, Whinam J, Selkirk PM, Convey P, Skotnicki M, Bergstrom DM (2005) Biological invasions in the Antarctic: extent, impacts and implications. Biol Rev 80:45-72

Hellberg ME (2006) No variation and low synonymous substitution rates in coral mtDNA despite high nuclear variation. BMC Evol Biol 6:24

Hickerson MJ, Meyer CP, Moritz C (2006) DNA barcoding will often fail to discover new animal species over broad parameter space. Syst Biol 55:729-739

McFadden CS, Alderslade P, van Ofwegen LP, Johnsen H, Rusmevichientong A (2006) Phylogenetic relationships within the tropical soft coral genera Sarcophyton and Lobophytum (Anthozoa, Octocorallia). Invert Biol 125:288-305

McFadden CS, Benayahu Y, Pante E, Thoma JN, Nevarez PA, France SC (2011) Limitations of mitochondrial gene barcoding in Octocorallia. Mol Ecol Res 11:19-31

Rubinoff D (2006) Utility of mitochondrial DNA barcodes in species conservation. Conserv Biol 20:1026-1033

Shearer TL, Van Oppen MJH, Romano SL, Wörheide G (2002) Slow mitochondrial gene evolution in the Anthozoa (Cnidaria). Mol Ecol 11:2475-2487

Smith VS (2005) DNA barcoding: perspectives from a "Partnerships for Enhancing Expertise in Taxonomy" (PEET) debate. Syst Biol 54:841-844

Tamura K, Peterson D, Peterson N, Stecher G, Nei M, Kumar S (2011) MEGA5: Molecular evolutionary genetics analysis using maximum likelihood, evolutionary distance, and maximum parsimony methods. Mol Biol Evol 28:2731-2739

van Ofwegen LP, Häussermann V, Försterra G (2006) A new genus of soft coral (Octocorallia: Alcyonacea: Clavulariidae) from Chile. Zootaxa 1219:47-57

van Ofwegen L, Breedy O, Cairns S (2009) Octocorallia-Octocorals. In: Häussermann V, Försterra G (eds) Marine benthic fauna of Chilean Patagonia. Nature in Focus, Chile, pp 178-214

Wiens JJ (2007) Species delimitation: new approaches for discovering diversity. Syst Biol 56:875-878 